\title{
EDUCATIONAL ATTAINMENT IN THE SOUTH ASIAN DIASPORA: REPRESENTATION OF GENDER CONFLICTS IN GURINDER CHADHA AND MIRA NAIR'S FILMS ${ }^{1}$
}

\author{
Jorge Diego Sánchez ${ }^{2}$
}

\begin{abstract}
Educational Attainment in the South Asian Diaspora: Representation of Gender Conflicts in Gurinder Chadha and Mira Nair's Films

Abstract: This article studies the representations that Mira Nair and Gurinder Chadha, film directors from the South Asian diaspora, offer to portray and denounce the educational attainment inequality suffered by women from the diaspora in the United Kingdom and the United States. The paper analyses how Chadha and Nair's depictions challenge the socioeconomic structures that limit these characters both in their homelands and in the welcoming countries and how they disrupt the limiting structures imposed on them for being women.

Key words: Gurinder Chadha, Mira Nair, diaspora, South Asian Subcontinent.

Logros educativos en la diáspora del Subcontinente Surasiático: La representación de los conflictos de género en las películas de Gurinder Chadha y Mira Nair

Resumen: Este artículo estudia las representaciones que las directoras de cine de la diáspora del Subcontinente surasiático Gurinder Chadha y Mira Nair realizan para presentar y denunciar la desigualdad que sufren las mujeres de esta diáspora en Reino Unido y Estados Unidos a la hora de acceder y elegir qué estudios realizar. Analizando algunos de sus personajes se demuestra que Chadha y Nair desafían el orden socioeconómico que limita a sus personajes tanto en sus comunidades como en el país que las recibe presentando mujeres transgresoras que rompen con las estructuras limitantes impuestas sobre ellas por el hecho de ser mujer.

Palabras clave: Gurinder Chadha, Mira Nair, diáspora, Subcontinente Surasiático.
\end{abstract}

\section{Introduction}

Educational attainment is a gender conflict and so Augusto López-Claros and Saadia Zahidi (2005) define it as "the main framework for capturing the magnitude and scope of the gender-based disparities" (3). Equally, The United Nations' The Millennium Development Goals Report 2009 recognised the "urgency" and "commitment" (18) that was required to guarantee equal access to academic education by 2015, an objective that

1 Date of reception: 10/10/2015.

2 Associate Professor, Departamento de Filología Inglesa, Universidad de Salamanca; $\square$ jorgediegosanchez@usal.es. 
failed to be completed. Correspondingly, touchstone studies on the South Asian diaspora in the United Kingdom and the United States ${ }^{3}$ also reflect how the access, refusal and imposition of an academic education acts as an artistic and creative evaluator of the contact among cultures and the subaltern position played by the migrant woman in its socioeconomic reality.

This article studies the gender conflicts that in terms of unequal educational attainment define the educational and professional opportunities of women in the South Asian diaspora as illustrated in a selection of films by South Asian female film directors. By conflicts, I refer to those situations in which women occupy a subaltern position in the homelands and in the diaspora in relation to the male population. The scope of cultural and artistic representations of the topic may seem proliferous, as there have been a certain number of novels that have enjoyed public and editorial recognition and that deal with this issue. Titles such as Bharati Mukherjee's Yasmin (1988), Monica Ali's Brick Lane (2002), Meera Syal's The House of Hidden Mothers (2015) or Jhumpa Lahiri's The Lowland (2014), The Namesake (2004) and Interpreter of Maladies (1999) are illustrative of this trend. Nevertheless, I will focus on the movies by filmmakers from the South Asian Diaspora Gurinder Chadha (1960-) and Mira Nair (1957-) because I consider that their trajectories of diaspora (respectively second and first generation in diaspora) and their commitment to break with the gender inequalities in cinema have been pioneering in the history of gender, postcolonial and cultural studies. ${ }^{4}$

Accordingly, I analyse in this paper how both filmmakers offer a representation of South Asian women in the diaspora (characters from first, second and third generation of South Asian women in the diaspora) not as mere victims but as promoters of social transformation and consciousness-raising about the unequal access to academic education. I will evaluate the characters of Mina and Kinnu in Mira Nair's Mississippi Masala (1991), Asha and Hashida in Gurinder Chadha's Bhaji on the Beach (1993), Ria in Nair's Monsoon Wedding (2001), Jess in Chadha's Bend It like Beckham (2002) and

\footnotetext{
${ }^{3}$ Works of reference in the study of historical and political variables include Rangaswamy 2000; Raghuram et al. 2003; Ali et al. 2004; Bhati 2007; Lal 2007; Safran; Sahoo and Lal 2009; Jayaram 2011; Sahoo 2012; Kumar 2015.

${ }^{4}$ For further information on Gurinder Chadha and Mira Nair see Diego Sánchez 2015.
} 
Ashima in Nair's The Namesake (2006) because they are clear exponents of the gendered nature of academic inequality in the access experienced by South Asian Women in diaspora. And they belong to different generations of the diaspora in the UK. Hereby, it is my intention to show the complex experience of Nair and Chadha's characters (no matter their economic or educational background because they are all under the same structures of patriarchal control that affect the three generations of women in the diaspora) as alternatives to the contemporary and reductionist stereotypes of the high skilled female IT workers in Manhattan and Silicon Valley in the US, the Muslim Bangladeshi woman dressed with a hijab or the perfect Hindu wife cooking chapattis and daily visiting the Mandir in the North of London.

\section{2. “A Mixed Masala": Mina in Mira Nair's Mississippi Masala}

Let me start by analysing the character of Mina in Mira Nair's Mississippi Masala (1991). Mina was born in Uganda but, as the beginning of the movie shows, her family moves firstly to the UK and then later to Mississippi (US). Mina is the daughter of Jay, an Indian barrister who feels Ugandan at his heart, where he was employed as a British officer following the Indenture system already explained in Chapter I. Nevertheless, the whole South Asian Community must leave after the new Ugandan president Idi Amin's Indictment against Indians (1972) and her father Jay, reluctant to abandon his "home" and "the country he was born in" (2'24' -2 '29', 17'43'), must cope with the idea that his Law education might be of no use beyond the Ugandan frontiers for, as Anil mentions, Jay was "the champion defendant in Uganda" (37'15'). ${ }^{5}$ For that reason, and after having enjoyed a privileged socioeconomic background in East Africa, the family moves to the UK and then to Mississippi in the US. In Mississippi, Mina and Jay work as clerks for their cousin's motel business. Here, Jay's academic expertise is useless and Mina must be employed as receptionist until she can afford a proper academic education, as she

\footnotetext{
${ }^{5}$ From here on, I will use the symbol (h) to refer to the hour, (") to denote to the minute and (") to point to the second of the movie from where the quotation is taken.
} 
explains to Jay in the lunch scene at the Chinese Restaurant (44'11' '-44'57''). Thence, in the US it is only Kinnu, Mina's mother, who has a business of her own: she runs a Likker Legger, a sort of traditional dukawalla (a shop selling South Asian products) and offLicense which, ironically, advertises the cheapness of American alcohol as opposed to the excellence of expensive British spirits (1h05'09'').

The paradox of the situation trespasses this description because Jay represents the paradigm of a highly skilled migrant in the US who does not get an appropriate job, unlike Kinnu, who is academically uneducated but, in the diaspora, feeds her family while she is subdued under Jay and his family's will. Accordingly, Mina is expected to marry an Indian migrant as her friend Namita does in the movie, as she is about to marry Anil (Mina's cousin). However, Mina will afterwards defy this burden imposed by her family and community by falling in love with African American Demetrius (starred by Denzel Washington in his first role on screen), illustrating that there is another possibility beyond the endogenous limitations imposed by the South Asian community. The community's reaction to Mina's affair can be summarised in the scene where Mira Nair and Sooni Taraporevala (screenplay writer of Salaam Bombay and Mississippi Masala) themselves star as the two gossipers talking on the phone about Mina dating Demetrius: "[Can] you imagine dumping Harry Patel for a black? . . . These modern ideas spread like a disease. Better send her back to India, get some ideas and be back to find a decent suitor" (1h17'21' '-1h18'18')). Moreover, Mina suffers from a white-normative yoke because, for instance, she is insulted by two white policemen who scream at her "you bitch" and she answer with "you motherfucker" (1h14'36") when she is discovered by the police and her Indian cousins in the hotel room with Demetrius. It is straight after this scene when Mina tells her father that she needs to "pursue an academic education" (44'11') to be free because, in Jay's own words: "They [referring to US white men] can take everything out of you but they can't take your education" (44'12''-44'16'). At this moment, she is denouncing the double submission she suffers both as a migrant and as a woman, as she suffers the yoke of both the US pro-male and pro-white norms in the early nineties (have they changed?) and the South Asian community pro-male organisation. 
Mina is, as Sinijita Bhatia ${ }^{6}$ remarks, an "emigrant twice displaced" (qtd. in Binita Mehta 1996: 187) who challenges the limitations that, in terms of educational attainment, are imposed on her for, as previously said, being both migrant and woman. Illustrative of the first statement is Tyrone's lines (Demetrius' brother) at Demetrius' grandfather's birthday party: "You cannot be dark and have money, no matter whether you are black, brown or yellow, we are not white" (41'31"). Likewise, Kinnu's words to Mina that "you are a girl and so must accept your responsibility [with the family]" (1h16'51',') are representative of the second.

Bearing in mind this subaltern context, it is also noteworthy that none of the female characters portrayed in the film have access to a university education, probably under the dictation that they must stick together around the family's motel and keep the good Indian customs, as I previously quoted the characters of the gossipers. Nonetheless, this statement is subverted by Mina, who fights against her imposed fate in order to challenge that unequal traditional system, as represented by her call at the end of the movie, when she tells her parents that she is running away with Demetrius to pursue a future for herself. In her own words: "If I don't leave now I will never leave" (1h40'49'”). In my opinion, this is Mina's opposition against the double gender burden imposed on her as, and paraphrasing the previously referred scene, she does not want to "spend [her] whole life working at a liquor store ... [because she thinks that she] can change the world" (1h41'58'). This beautiful image (alongside the whole interracial relationship that will be analysed in next section) clearly represents Mina's desire to break the gender norm imposed on her educational future.

Furthermore, Mina's economic unfeasibility to access university education may be subverted if she realises about the professional possibilities within the diaspora space

\footnotetext{
${ }^{6}$ I consider that Bhatia's essay is not an accurate reading of the stimulating essay by Parvinder Bachu's "Twice-Born Migrants" (1985). On the one hand, Bhatia only acknowledges "the particular idiosyncrasy of the twice, thrice, and quadrant migrant experiences of the South Asian diasporas around the Asian, African, Caribbean and British/American shores" (183) and defines Mississippi Masala as a mere "story of emigrants twice displaced by issues of race, colour and identity which never trespasses the idea of integrating Mina and Demetrius' families within the prospects of a common future beyond [Mina's] motel and [Demetrius'] cleaning enterprise" (187). On the other hand, Bhachu recognised the connivance of the four cultures (South Asian, African American, Latino and WASPs) and the possible formation of a hybrid identity.
} 
beyond the limits placed by her community. Here, the fact that the US occupies the fortieth position (out of one hundred and forty-five) on the World Economic Forum's Gender Gap Global Report of $2015^{7}$ in terms of educational attainment and the seventy fouth (out of one hundred forty five) in terms of equality of wage proves that Missississpi Masala (1991) is still very relevant today. If Mina represents a change towards progressive subversion as compared to Kinnu, so do Asha and Hashida in Gurinder Chadha's Bhaji on the Beach (1993).

\section{3. "Duty. Honour. Sacrifice": Asha and Hashida in Gurinder Chadha's Bhaji on the Beach}

Bhaji on the Beach opens showing the display windows of a street in Birmingham with Nazi graffiti, hybrid supermarkets (as the baskets of a grocery store exhibit "coriander and mangoes from India" alongside British pomegranates and French apples, 20'-23') and the typical South Asian video rental shop with formulaic Hindi Popular cinema billboards. The camera vision enters into the shop and the action switches to display Asha's nightmares. Asha is a woman in her forties and the assistant at the video rental shop. Rama, the Hindu god who killed Sita, the paradigm of the good-wife to be imitated by Hindu female believers, scolds Asha. In these nightmares that are repeated throughout the whole movie and that feminist critic Geetha Ramanathan refers to as "Asha's extradiegetic visions" (2006: 67), Hindu god Rama always reminds Asha that she "must be a proper Indian wife and follow [her] traditional education, what it is expected from [her]" (6'). The film will later reveal that Asha's true aspirations were not those of working at her husband's video shop but being a Bollywood ${ }^{8}$ actress, as Asha

\footnotetext{
${ }^{7}$ An earlier version of this research was gathered in the MPhil dissertation "Hybrid Cinemas and Gender Representations in the South Asian Diaspora: The Films of Gurinder Chadha and Mira Nair" (Diego Sánchez 2010). The research in this study analysed figures from 2009 and, in terms of educational attainment, they were better as they positioned the US in the twenty-seventh position.

${ }^{8}$ The 1990s congratulated the so-called Bollywood (a retake of Bombay and Hollywood) as a popular manifestation of Indian colourful saris and Ancient grandiosity. Nevertheless, the label Bollywood normally involves a certain Orientalist and simplistic reading of the Indian culture, in the fashion of
} 
herself tells the English gentleman in Blackpool: "I wanted to become a Bollywood actress but, after getting married, I quitted my singing and acting" (78'). It is at this moment that Asha realises that, as Kinnu in Nair's Mississipi Masala, she is the one feeding her family because her husband is never over the counter at the video-rental shop, as it is hinted in the third nightmare (58'), where her husband gives orders about how to work at the shop and cook warm chapattis while he socialises at the bar. When she says goodbye to Ambrose Waddington, the English man she meets in Blackpool, she grumbles: "Maybe I should resume my singing lessons" (43'59').

It is at this moment that Asha comes to terms with the gender restriction that she herself, as one of the community's aunties, is also imposing on characters like Hashida, a character who faces a triple yoke. Firstly, Hashida cannot study an Arts degree because her family and her community have already decided that she must become a doctor. Secondly, she has a secret interracial relationship with Oliver, a black man who studies Arts and that, obviously, will not be welcomed by her South Asian family. And, thirdly, she has found out that she is pregnant scarcely before starting the trip to Blackpool, something that will be discovered by the rest of the women in the trip, who will refuse Hashida after they discover that she is pregnant, as they call her "besharam" (41'34'), which means prostitute or woman without honour. I hereby consider that the parallel created by both Gurinder Chadha and the screenplay writer Meera Syal in the character of Hashida is very important to understand how education is interwoven in the triple axis that illustrates Hashida's unequal position as a migrant woman in terms of economic participation, social opportunity and political empowerment.

exoticism (such as the Selfridge's exhibition in the summer of 2000) and propagandistic cultural simplification. Thence, the Bollywood label normally involves the description of the Hindi movies that, from the British introduction of cinema in India in 1930s, continue to write stereotypes of Hindutva conservativism (which aim at fostering extreme Hindu politics for the whole secular society of India). The popular Hindi movies still continue to present classic melodramatic stories in which India is depicted as a society split in castes (not varnas) inheritor of the Aryan grandiosity where women are to be victimised. Films like Sanjay Leela Bhansali's Devdas (2004), Ashutosh Gowariker's Lagaan (2005) and Jodhaa Akbar (2008) or Kabir Khan's Bajrangi Bhaijaan (2015) are perfect instances of the Bollywood film that must be comprehended from the stereotypical gaze expected from Bollywood. The songs and dances are a key part of the movie, normally with propagandistic purposes (both political and economic). 
In this sense, it is remarkable that out of all the women in the trip to Blackpool, it is only Manjit, who is in charge of the Non-Governmental Organisation that arranges the trip, and Hashida, who has prospects for education attainment, ${ }^{9}$ who have a potential future in terms of professional freedom. At this juncture, it is proven that the choice of academic education of the South Asian woman in the diaspora is very much dependent on her family's hopes, especially her father's, as Hashida will study because her father has determined her to do so and go to university to study Medicine, despite the fact that she wants to study Arts (9'58') $){ }^{10}$ In this regard, Gurinder Chadha recognises the genderdesigned barriers in both education and subsequent access to employment to promote the integration of Hashida within the possibilities of the diaspora space, where both women and men, migrant or not, can be economically active and politically participative. It is now important to remember this challenge because the United Kingdom is placed the forty-eighth country in equal wage in the World Economic Forum's Gender Gap global Report of 2015 in terms of educational attainment.

Also, it is under the subversive terms of the film that, after the final scene at the male striptease club (when they all discover that Ginder has been mistreated by her husband and so the aunties had all been wrong accusing her of just leaving her husband), Asha changes her mind and enhances the construction of a collaborative space with the rest of the women so that Hashida and Ginder can find empathy and spiritual comfort. It is in this nurturing space of collaboration where Asha defends Ginder for the first time and states to Ginder's husband: "Put that boy down [referring to Ginder and his son] and leave her alone" (1h29',51). The scene is very moving because the rest of the women smile with a knowing smile first at Ginder and then to Hashida when they see her from

\footnotetext{
${ }^{9}$ It is very important to note that both Manjit and Hashida are the only women in the trip who support Ginder who, having left her husband because he abused her, is rejected by the rest of the South Asian community.

${ }^{10}$ The following academic references illustrate this statement referring to both the UK and the US: Jonathan Beaverstock's "Rethinking Skilled Labour Migration: World Cities and Baking Organisations" (1994), Fauzia Ahmad et al.'s South Asian Women and Employment in Britain: The Interaction of Gender and Ethnicity (2003), Ernst Spaan et. al's Asian Migrants and European Labour Market (2005), Tariq Modood et al.'s Ethnicity, Social Mobility, and Public Policy: Comparing the USA and UK (2005), Joel Kuortti's Writing Imagined Diasporas: South Asian Women Reshaping North American Identity (2007), Yasmin Hussain's Moving on Up: South Asian Women and Higher Education (2007), Barnita Bagchi, Eckardt Fuchs and Kate Rousmaniere's Connecting Histories of Education. Transnational and Cross-Cultural Exchanges in (Post-)Colonial Education (2014).
} 
the bus with Olivier when the bus resumes its journey back to their daily routines in Birmingham (1h32'39'). Once they are back on the bus to return home, they talk about how Hashida is a modern woman that will help the rest of the women of the community, either becoming a doctor or an artist. They all trust the subversive opportunities that Hashida has ahead of herself in the diaspora space, a space from where the South Asian women on the trip have constructed a parallel mutual alliance against patriarchal and social limitations. Now, Hashida has a future of her own by being able to choose the Arts Degree she longs for and so Ginder or Asha recognise themselves as common inhabitants of the subversive hope inherent to the diaspora space. Hope is here defined following Henry A. Giroux's article "When Hope Is Subversive" (2004), where he defines hope as follows:

\begin{abstract}
[Hope] is more than a politics, it is also a pedagogical and performative practice that provides the foundation for enabling human beings to learn about their potential as moral and civic agents ... Hope is anticipatory and mobilizing[,] is a subversive force [that] pluralizes politics by opening up a space for dissent, making authority accountable, and becoming an activating presence in promoting social transformation. ... Hope [is] a subversive force, a defiant practice that provides a link, however transient, provisional and contextual, between vision and critique on the one hand, and engagement and transformation on the other. (38-39)
\end{abstract}

Accordingly, the character of Ria in Mira Nair's Monsoon Wedding (2001) is a further illustration of this confrontation that, in terms of educational choice, appears between what is expected from a woman and what she truly desires.

\title{
4. "I want to be free": Ria in Mira Nair's Monsoon Wedding and Ashima in Mira Nair's The Namesake
}

In Monsoon Wedding, Ria is the only female character in the Verma family that decides to undertake an academic education and so she challenges the schemes dictated 
by her aunt-mother (Ria is an orphan), who constantly tells Ria and her cousin-sister Aditi that "there will be a time when all of you will fly out when your wedding is arranged" (12'). Nevertheless, Ria decides to oppose this fixed idea in between the preparations for Aditi's arranged wedding. At this stage, and considering how Aditi must choose between the affair she is having with a married man and her own arranged marriage, Ria decides to speak out and inform all the family that she wants to study Creative Writing in the US "to make sense of all her life" (44'). Soon all the men in the family gather to decide what to do. The decision made is that Ria can go to the US under the patronage of her uncle Tej, the most economically successful man in the family who has flown to Delhi from the US for Aditi's wedding.

However, Ria's expression of disgust is clear. She keeps silent until right before the ceremony, when she decides to talk back and denounce her uncle Tej for having abused her when she was a teenager, something that she fears he is probably doing now to the little cousin Aliya (1h33'11'), Ria asserts that, at a moment when she has decided to fight for a future of her own, she needed to take all her conflicts out and break all the decisions that for her future have been laid upon her (1h33'22''). At this moment, all the family members grumble back at her and complain about how being a spinster has definitely troubled her mind (1h34'24'). Right afterwards, when they are settled to take the family snapshot before the wedding's ceremony, Lalit Verma (Aditi's father and Ria's uncle-father) decides to reject uncle Tej in the photograph arguing that "Ria is [his] daughter ... [he] support her and [he believes] in her. You [to uncle Tej] go out" (1h42'26'). It is then that, under the prospects of starting academic education, Ria subverts the assigned gender-expectations sketched by her family as she will be the first woman in the family to follow an academic education, as compared to the interest that Lalit (Ria's uncle/father) has always imposed on his son Varum's educational expectations for the fact of being a man, and specifically the man of the family (1h12'10'). Consequently, Ria's educational attainment would subvert what was expected from her as an orphan and economically dependent woman because she will finally manage to gather the necessary family, social and economic support that she needs 
to start her studies in Creative Writing. So, she will become a writer of the world who will be able to show the path to freedom and equality to other women.

This situation mirrors the opening of Mira Nair's The Namesake (2006) when Ashima first encounters, on the threshold of her Kolkata's home, a pair of sparkling shoes made in the US while she listens to her own mother stating: "[Ashima] loves to cook. She knits very well. Kids are crazy about her. She has been learning classical music since she was a kid. She goes to college and her best subject at is English poetry" (9'12')' Ashima tries Ashok's shoes on and listens to Ashok's mother stating: "My son has been living abroad for the last two years. He is in New York. He is doing his PhD in the field of Fibre Optics" (9'26'). Ashima ushers into the room, meets Ashok and recites a poem by Alfred Tennyson. Immediately, Ashok's mother asks Ashima: "My child, have you ever flown in a plane? Will you be able to live in the other half of the world? Live in a cold city with freezing winters? Leave your house, far from your parents?" (9'30') . Ashima answers: "But he'll be with me, no?" (9'31'), therefore illustrating her expectations about an Indian arranged marriage of staying at home subduing her life to her husband's necessities. However, as the action moves to New York, Ashima gives birth to her son Gogol and realises that she is to wait every afternoon for Ashok to come back from work, taking into account the fact that she is not able to do anything in the US because Ashok is used to doing everything by himself.

It is in this context that Ashima realises how she gave up her education back in India after getting married and how she lost her possibility to become an active part in the economic dynamics of the diaspora space. Nevertheless, once her children Gogol and Sonia leave for college, she starts to work at a local library and enriches her private life talking with other women, turning to the idea of resuming her education as a singer, ${ }^{11}$ as she herself claims to her colleague Sally and later to her family" (1h38'23', 1h49'27' '). This space that both Ashima and Sally have created at the library soon emerges as an alternative place to the assumed family and social expectations previously sketched for

\footnotetext{
${ }^{11}$ It is interesting to point out that the characters of Ashima, Asha, Ria and Hashida all want to become artists despite their husband's or the family's opposition. These four women who struggle to become free women and who fully participate in the dynamics of the diaspora space could prove by further academic studies how to open new creative spaces that empower other women.
} 
Ashima, who now shares confidences and personal stories outside her home. It is out of the strength of this collaborative friendship that Ashima reveals to Sally that she has been thinking about leaving the US (1h38'23'). Mira Nair's "Director's Commentary" in the British DVD edition for The Namesake illustrates this remark. In Nair's own words: "This is the first moment where Ashima clearly has an opportunity to express and act as herself" (12'). Thus, the next decision taken by Ashima would be that of selling her house in the US because her children do not live with her any longer, they do not depend on her any longer and so she can live six months in India and six in the US. In India, she will go back to her family home in Kolkata, where she will go back to her music lessons and artistic education. In the US, she will live with her children and keep on with her singing (1h41'10',).

The scene clearly illustrates the cycle Ashima unveils to embrace the nature of her own name and her own existence, as she explains to her children: "I want to go back to where I belong [that's why] . . I have decided to sell the house. I am going to do what your father and I had always planned. Six months in India and six months in the US. Then I can go and sing in Calcutta. That is if any guru wants a forty-five year old student. I want to be free" (1h40'37'-1h40'55'). At this moment, I consider that Ashima embraces the transformative dynamics of the diaspora space and a corresponding life dependant only on her own choices. ${ }^{12}$ Once Ashima is able to be part of the economic system, she resumes her education and enjoys a much wider social opportunity that grants her with the possibility of living as she truly desires.

\footnotetext{
${ }^{12}$ I consider significant to point out that the film starts and finishes with an image of Saraswati, the Hindu goddess of the Arts who, as explained in the Upanishads, destroys Vritasura, the God who had stolen all the water and knowledge of the world. Here, Saraswati is represented with four attributes, a dish with holy water (as exponent of the power to purify and give life), a mala (a necklace representative of the meditative power), a book (which is an anachronism explained by the fact that print books only arrived at the Subcontinent under British Empire occupancy) and the Sitar (illustrative of the search for perfection and the constant transformation of every artist in the quest for freedom-moksha). Consequently, it is not a matter of coincidence that Nair chose that Ashima trains as a sitar singer and that her name means without frontiers. Ashima is then the exponent of a woman in constant transformation who benefits from the power of art along her path towards moksha.
} 


\section{5. "The answer to England's pressing needs": Jess in Chadha's Bend It like Beckham}

Similarly, the character of Jess in Gurinder Chadha's Bend It like Beckham (2002) serves as the perfect corollary to illustrate and summarise the interconnection among educational attainment, economic participation and social opportunity opened by the theoretical recognition of the diaspora space. Gurinder Chadha herself asserts: "Bend It like Beckham illustrates how women need to acknowledge their own role in the dynamics of the world, bend the world to them, as we wanted to transmit by the title of the feature" (2006: 2). Chadha's words clearly connect with Amartya Sen's previously referred statement, where Sen proclaims: "[Societies] need to see women less as passive recipients of help, and more as dynamic promoters of social transformation ... suggesting that the education, employment and ownership rights of women have a powerful influence on their ability to control their environment and contribute to economic development" (qtd. in Lopez-Claros and Zahidi, 3). Here, the fact that Jess, together with white British Jules, finally accomplishes the same opportunity of education and economic participation as that given to male football players clearly proves the necessary commitment that must be taken towards the performance of gender equality. Once again, the subversive hope of the role of the migrant woman in the diaspora space is implicit, since the opening scene of the film when, in Jess's dream, Mrs Bhamra is interviewed on TV and asked: "Could Jess be the answer for England's pressing needs?" (1'23'). And, in fact, Jess establishes herself as the paradigmatic figure from where to review the cultural and racist reasons that generate the gender inequality of women in the diaspora space.

Jess is a second generation Punjabi born in the UK, a seventeen-year-old girl who dreams about becoming as famous as footballer David Beckham. Jess sneaks out daily to play football with some of the male South Asians in her neighbourhood and then works hard to pass her A Levels (equivalent to the High School Leaving Certificate necessary to enrol in a university degree) to fulfil her family's hopes. In this sense, Jess will probably go to college as her father exclaims when she gets the A Levels results (1h12'). The fact that Jess may study a serious degree such as Medicine or Law would illustrate, for her father's opinion, a certain progress and a social acknowledgement for the Bhamra 
family because her father works at Heathrow Airport and her sister Pinky at Lutton (probably as members of the crew and the handling company respectively), meanwhile her mother is always, as she herself exclaims, "too busy trying to keep the Indian values over my girls" (8'40'). This objective is partly fulfilled by Pinky's marriage because, although it is a love marriage, the groom's family is decent (8'40'), However, Jess' feelings towards her sister's wedding stand on the opposite: "I am sick of this wedding and it hasn't started"' (8'54')).

After this remark, it is significant to point out how the action changes to show Jess running to the park to meet Jules (starred by Keira Knightley), who invites Jess to join her all-girls football team. Jess answers: "I didn't even know that there were girls' teams" to which Jules replies by exclaiming that her dream is, in her own words, "[to] play professional in America. You know, they have got a pro-league, stadiums, money, respect and they provide an academic education at the same time [sic]" (18'08'). Jess accepts the invitation and tells her parents. Mrs Bhamra's reaction unveils as follows:

\begin{abstract}
Jessminder, I don't want shame on my family ... You have to start behaving as a proper woman, ok? I don't want you running around people half-naked in front of men, look how dark you have become playing under the sun. No family will want a daughter in law who plays football non-stop. You can go and play round football but you can't make round chapattis. Once your exams are over you are starting to learn how to cook a proper Punjabi dinner. (21'14''-21'49'")
\end{abstract}

In this sense, Jess's educational attainment is corroborated as a family expectation, something that she cannot choose for herself as already explained when describing the character of Hashida in Gurinder Chadha's Bhaji on the Beach (1993). Afterwards, Jess tells Jules that she is "ready to surrender to her culture and quit football" to which Jules reacts: "That's bollocks; my mother does neither want me to play [sic]. You can't take a no for an answer. There is an American scout coming over to see us playing Jess, you can't turn an opportunity for a future of your own. Tell your mum you are working at HMV" (22'54' '-23'08' '). At this moment, Jess decides to embrace a fate of her own and defy all those patriarchal, cultural and racial expectations placed on her. Chadha 
paradigmatically decides to underscore the moment when they travel to Germany and British singer (former Spice Girls member) Mel C's song “This is my Independence Day” is played. The song, from which I later quote the chorus, clearly illustrates how Jess challenges the gender limitations imposed on them by her family: "I know I make mistakes/I will have to live and learn. . I've got to find my way and my independence day" (31'20' '-31'50'). By so doing, Jess has decided to reject the family expectations placed on her as the means to choose what she really wants.

Further in the film, and by finally being selected by the American scout alongside Jules, Jess performs a social transformation. She will be the first South Asian woman in a Professional Football League, as opposed to her father, who had to quit playing cricket once he arrived in England because, in her own words, "I did not want to challenge my racist mates and my conservative father so I just did what my father told me to do ... There were no visible Indians boys out there in the limelight" (1h35'4'). Jess suffered the same problem when insulted "Paki bitch" in the middle of a match (1h03'-1h04' 50 '), but she will act in response and, although overreacting, spit back at her rival. This is what she also does at the end of the film, when she talks back to her community and family to inform them that she is going to America to study and play football. In Jess's own words:

I played the best and I was happy because I wasn't lying to you. . . I didn't ask to be good at football, Nanak would have blessed me. . . . There was a scout from America and he has offered me a place at a top university with a full scholarship and a chance to play football professionally. And I really want to go. If I can't tell you what I will like to do now I won't ever be happy. (1h34'56')

Thus, Jess opens an opportunity for herself and, by so doing, she challenges the whole interlocking systems that were placed on her as both being a woman and a migrant. Accordingly, Jess is a character that promotes awareness and fosters the challenge inherent to the transformative power of the diaspora that Nair and Chadha draw for their female characters. 


\section{Conclusion}

The previous pages have illustrated how both Gurinder Chadha and Mira Nair offer a representation of the subaltern position of the migrant woman by focusing on the topic of access and choice of academic education and so I have analysed the characters of Mina, Asha, Hashida, Ria, Ashima and Jess as illustrators of Chadha and Nair's denouncement on the gender limitations that are still placed on the migrant woman. Likewise, this study has proved how Chadha and Nair recognise the subversive possibility inherent in the diaspora as a true impulse from where to contest gender discrimination inherent both to the South Asian community and to the UK and the US normative expectations.

Therefore, and strictly derived from the previous point, both Nair and Chadha portray characters who share a collaborative space where migrant women meet together so as to finally negotiate the subversive power of their hybrid, diasporic identities. This is the point of departure for future studies that should study the gender conflicts associated with the arranged marriages and the interracial love relationships described by Chadha and Nair as a way to show the transcultural possibilities of the South Asian women in the diaspora space.

\section{References}

Ahmad, Fauzia y Tariq Modood. 2003. South Asian Women \& Employment in Britain. The Interaction of Gender and Ethnicity. London: Policies Studies Institute.

Ali, Monica. 2002. Brick Lane. London: Harper Collins.

Ali, Nasreen y Virinder S. Kalra y Siddiq Sayyd, eds. 2004. A Postcolonial People. South Asians in Britain. London: Hurst \& Company.

Bagchi, Barnita and Eckardt Fuchs and Kate Rousmaniere. 2014. Connecting Histories of Education. Transnational and Cross-Cultural Exchanges in (Post-)Colonial Education. Oxford: Berghahn. 
Beaverstock, Jonathan. 1994. "Rethinking Skilled Labour Migration: World Cities and Baking Organisations." Geoforum, 25: 323-338.

Bhachu, Parvinder. 1985. Twice Migrants: East African Settlers in Britain. London: Routledge.

Bhansali, Sanjay Leela (dir.). 2002. Devdas. Mega Bollywood St.

Bhati, Sunil. 2007. American Karma: Race, Culture, and Identity in the Indian Diaspora. New York: New York University Press.

Chadha, Gurinder (dir.). 2002. Bend It like Beckham. Kintop Pictures, Film Council, Filmförderung Hamburg, British Sky Broadcasting (BSkyB), Helkon Media AG, Scion Films, Bend It Films, Roc Media, Road Movies Filmproducktion, Future Films.

1993. Bhaji on the Beach. Umbi Productions and Channel Four Films.

Diego Sánchez, Jorge. 2015. Hybrid Cinemas and Narratives: Gender Representation in Women's Cinema of the South Asian Diaspora. Universidad de Salamanca. http://gredos.usal.es/jspui/handle/10366/126107. [7 oct. 2015].

2010. "Hybrid Cinemas and Gender Representations in the South Asian Diaspora: The Films of Gurinder Chadha and Mira Nair". Universidad de Salamanca (MPhil dissertation). http://gredos.usal.es/jspui/bitstream/10366/1/TG_ DiegoJorge_HybridCinemasAndGender.pdf. [31 May 2015].

Giroux, Henry A. 2004. "When Hope is Subversive.” TIKKUN, 19 6: 38-39.

"Global Gender Gap Report 2014". World Economic Forum. http://www3.weforum.org/docs/GGGR14/GGGR_CompleteReport_2014.pdf. [28 Jun. 2015].

“Global Gender Gap Report 2015". World Economic Forum. http://www3.weforum.org/docs/GGGR14/GGGR_CompleteReport_2015.pdf. [31 May 2015].

Gowariker, Ashutosh (dir.). 2008. Jodhaa Akbar. Ashutosh Gowariker Productions Pvt. Ltd., UTV Motion Pictures.

2001. Lagaan. Aamri Khan Productions, Ashutosh Gowariker Productions Pvt. Ltd.

Hussain, Yasmin. 2007. Moving on Up: South Asian Women and Higher Education. Stoke-on-Trent: Trentham Books.

Jayaram, N. (ed.). 2011. Diversities in the Indian Diaspora: Nature, Implications, Responses. Delhi: Oxford University Press. 
Khan, Kabir (dir.) 2015. Bajrangi Bhaijaan. Eros International. Kabir Khan Films, Rockline Entertainment.

Kumar, Pratap. 2015. Indian Diaspora: Social-Cultural and Religious Worlds. Leiden: Brill.

Kumar Sahoo, Ajaya. 2012. Indian Diaspora and Transnationalism. New Delhi, Rawat.

Kuortti, Joel. 2007. Writing Imagined Diasporas: South Asian Women Reshaping North American Identity. Cambridge: Cambridge Scholar Publishing.

Lahiri, Jhumpa. 2014. The Lowland. New York: Vintage.

2003. The Namesake. New York: Harper. 1999. The Interpreter of Maladies. New York: Flamingo.

Lal, Brij V. 2007. The Encyclopaedia of the Indian Diaspora. University of Hawaii Press.

López-Claros, Augusto and Saadia Zahidi. 2005. Women's Empowerment: Measuring the Global Gender Gap. Geneva: World Economic Forum.

Mehta, Binita. 1996. "Emigrants Twice Displaced. Race, Color, and Identity in Mira Nair's Mississippi Masala." Between the Lines. South Asians and Postcoloniality. Ed. Deepika Bahri, and Mary Vasudeva. Philadelphia: Temple. 185-204.

Modood, Tariq, Steven M. Teles \& Glenn C. Loury (eds.). 2005. Ethnicity, Social Mobility, and Public Policy: Comparing the USA and UK. Cambridge: Cambridge University Press.

Mukherjee, Bharati. 1989. Jasmine. New York: Virago Press.

Nair, Mira (dir.) 2006. The Namesake. Fox Searchlight Pictures, Cine Mosaic, Entertainment Farm (EF), Cinem Mosaic, Mirabai Films, UTV Motion Pictures.

. 2001. Monsoon Wedding. Dir. Mira Nair. IFC prdocutions, Mirabai Films, Keyfilms Roma, Pandora Filmproduktion, Paradis Films, Baron Pictures (II), Delhi Dot Com.

1991. Mississipi Masala. Black River Productions, Channel Four Films, Cinecom Pictures, Mirabai Films, Movie Works, Odyssey Motion Pictures, Studio Canal Souss.

Raghuram, Parvati \& Nirmal Puwar (eds.). 2003. South Asian Women in the Diaspora. New Delhi: Berg Publishers.

Ramanathan, Geetha. 2006. Feminist Auteurs. London: Wallflower.

Rangaswamy, Padma. 2000. Namasté America. Chicago: Pennsylvania University Press. 
Safran, William, Ajaya Kumar Sahoo and Brij V. Lal. 2009. Transnational Migrations: The Indian Diaspora. Delhi: Routledge India.

Syal, Meera. 2015. The House of Hidden Mothers. London: Doubleday.

Spaan, Ernst, Felicitas Hillmann \& Ton van Naerssen. 2005. Asian Migrants and European Labour Markets. London: Routldege Research in Population and Migration.

The United Nations Department of Economic and Social Affairs. 2009. "The Millenium Development Goals Report". New York: United Nations. 